\title{
Comparison of Coal Reserve Estimation Methods, Case Study PT Bukit Asam Area, South Sumatra, Indonesia
}

\author{
Taufiq Muhammad Wijayanto ${ }^{1}$, Wahyu Wilopo*1, I Gde Budi Indrawan ${ }^{1}$, and Sunarko ${ }^{2}$ \\ ${ }^{1}$ Department of Geological Engineering, Faculty of Engineering, Universitas Gadjah Mada, Yogyakarta, Indonesia \\ ${ }^{2}$ PT. Bukit Asam Tbk.
}

\begin{abstract}
The calculation of coal reserves is influenced by the dimensions or size of the coal deposit. There are several types of coal reserve calculation methods, and the use of these methods is adjusted to existing geological conditions. Each method will produce a different amount of coal reserves, although the location is the same. This research compares coal reserve estimation methods with a case study in PT. Bukit Asam Area, South Sumatra, Indonesia. Data on coal thickness and topography are used as the basis for reserves estimation. Several methods are applied to estimate coal reserve: nearest neighbor point (NNP), inverse distance weighted (IDW), and kriging using Surfer 13 software. Coal deposits in the study area belong to the Muara Enim Formation, consisting of seam A1, seam A2, seam B, and seam C. The coal layers have an N $87^{\circ}$ E strike and dip $15-40^{\circ}$ to the south. Coal in this study area is classified as sub-bituminous rank coal with a coal calorific value $<7000$ calories / gram (dry ash-free) in seam B and coal calorific value $>7000$ calories/gram (dry ash-free) in A1, A2, and C seams. The selection of the best method for estimating coal reserves is based on the smallest root mean square error (RMSE) value. RMSE calculations are carried out for each interpolation of coal thickness on Seam A1, Seam A2, Seam B, and Seam C. The reserves estimation results indicate that kriging is the best method by providing the smallest error value with an RMSE value of 0.67 and coal reserves of 27,801,543 tons.
\end{abstract}

Keywords: Coal $\cdot$ Reserve estimation $\cdot$ Nearest neighbor point $\cdot$ Inverse distance weighting $\cdot$ Kriging.

\section{INTRODUCTION}

Indonesia is one of the world's countries with considerable coal reserves of 37 billion tons (Oktaviani, 2018). Coal is one of the alternative energy sources that are very potential to be developed in Indonesia due to the decreasing of oil and gas energy. PT. Bukit Asam Tbk (PTBA) is one of the coal mining companies in Indonesia founded on March 2, 1981, based on Government Regulation No. 42 of 1980. Currently, PTBA has a Tanjung Enim Mining Unit (UPTE) in the Tanjung Enim area, South Suma-

\footnotetext{
${ }^{*}$ Corresponding author: W. WILOPO, Department of Geological Engineering, Universitas Gadjah Mada. Jl. Grafika 2 Yogyakarta, Indonesia. E-mail: wilopo_w@ugm.ac.id
}

tra, as open-pit mining. PT. Bukit Asam Tbk was producing 28.5 million tons of coal in 2019, and in 2020 the production target is increased to 30 million tons.

Coal reserves are part of coal resources that dimensions, quantity, and quality are already known, which were declared to be mineable at the time of the feasibility study (BSN, 1999). The calculation of mineral deposit reserves is determined by the deposited material's dimensions or size (Widodo et al., 2015).

This research compares coal reserve estimation methods based on the existing pit design. The study will provide information on the best coal reserve estimation method in this area using Root Mean Square Error (RMSE) as a pa- 
rameter. The lowest RMSE values indicated the best model. The research area was located in the Muara Tiga Besar Mining Area, Muara Enim, South Sumatra Province, as shown in Figure 1. The mining area belongs to PT Bukit Asam Tbk, where mining activity has not been carried out at the moment.

\section{Regional GeOlOGy}

The research area is situated in the South Sumatra Basin (Bishop, 2001). The basin is a backward arc-shaped during the east-west trending extension phase in the pre-tertiary and early tertiary ages (de Coster, 1974).

Coal in this area is part of the Miocene Muara Enim Formation, shaped during the regression phase of the Neogen deposition cycle (de Coster, 1974). Each seam has a regular pattern of ash content thickness and branching. It also is widely distributed in the whole area. The burial process controls regional coal formation (Stalder, 1976).

The commercial coal seam is in the Muara Enim Formation (Subastedjo, 1983). Stratigraphically, the coal seam layers are divided into Mangus coal (Seam A), Suban coal (Seam B), and Petai coal (Seam C), as shown in Figure 2. The Mangus coal seam consists of Seam A1 and Seam A2 in the research area. The Muara Enim Formation consists of six coal seam layers (Susilawati and Ward, 2006). Seam A1 (Upper Mangus) consists of bright-banded coal with dull coaly claystone coal at the top and dull, bright coal lamination near the bottom (Pujobroto, 1997). Seam A1 has pelletoidal claystone, commonly referred to as tonsteins. It is high-rank coal with a thickness ranging from $2.5 \mathrm{~m}$ in the intrusion zone to $9.83 \mathrm{~m}$ in the lowrank coal zone. Seam A2 (Lower Mangus) is dominated by bright-banded coal, and its thickness varies from 4 to $13 \mathrm{~m}$. A silicified coal layer with a thickness is around $10-20 \mathrm{~cm}$ was found at the top of the coal seam. Seam B1 (Upper Suban) has a thickness from 5 to $14 \mathrm{~m}$ and no tonstein layer as impurities on this layer. Seam B2 (Lower Suban) has a thickness from 2 to 6 $\mathrm{m}$ and a tonstein layer in the seam's middle. The bright-banded coal is dominated in the upper part of the layer, and dull-banded coal in the bottom part. Seam C (Petai) has a thickness from 7 to12 $\mathrm{m}$ with four layers of 5 to $15 \mathrm{~cm}$ clay thickness. Seam $C$ also has higher sulfur content than other coal layers; occasionally, pyrite is also found in the coal.

\section{ReseARCH Methods}

The research data consist of borehole coordinate and elevation, coal thickness data, coal density data, and topographic data. Total available borehole data is 27 , with a depth varying from 58.2 to 262.5 meters from the surface, as shown in Figure 3. Excavation estimation using the block method can be done by making imaginary lines in the calculated objects' area. In general, this block method is used for minerals with thickness with high homogeneity and a reasonably even distribution area, such as coal (Laksono et al., 2018).

The caloric value is $<7000$ calories / gram (dry ash-free/DAF) is brown coal, and if the caloric value $>7000$ calories/gram (DAF) is hard coal and minimum coal thickness for estimation is $>0.4$ meters for hard coal and $>1$ meter for brown coal (BSN, 1999). The coal reserves can be calculated with the following equation (Wood et al., 1983).

$$
\text { Coal Tonnage }=A \times B \times C
$$

Where:

$$
\begin{aligned}
& A=\text { Average coal thickness }(\mathrm{m}) \\
& B=\text { Specific gravity of coal }\left(\mathrm{ton} / \mathrm{m}^{3}\right) \\
& C=\text { Total area included }\left(\mathrm{m}^{2}\right)
\end{aligned}
$$

Interpolation is the process of predicting the values of attributes at unsampled sites (Dag and Ozdemir, 2013). In this study, three interpolation methods are used to interpolate the coal thickness data, namely NNP (Nearest Neighbor Point), IDW (Inverse Distance Weighted), and kriging using Golden Surfer 13 Software. The detail of each method as follows:

\subsection{Nearest neighbor point (NNP)}

The NNP method, or also commonly referred to as the closest sample polygon method, is a method in which the estimated value of a point is based on each point's effect following the nearest point. This method is generally used in relatively homogeneous deposits and has a simple geometry shape (Hartman, 1992). In the 


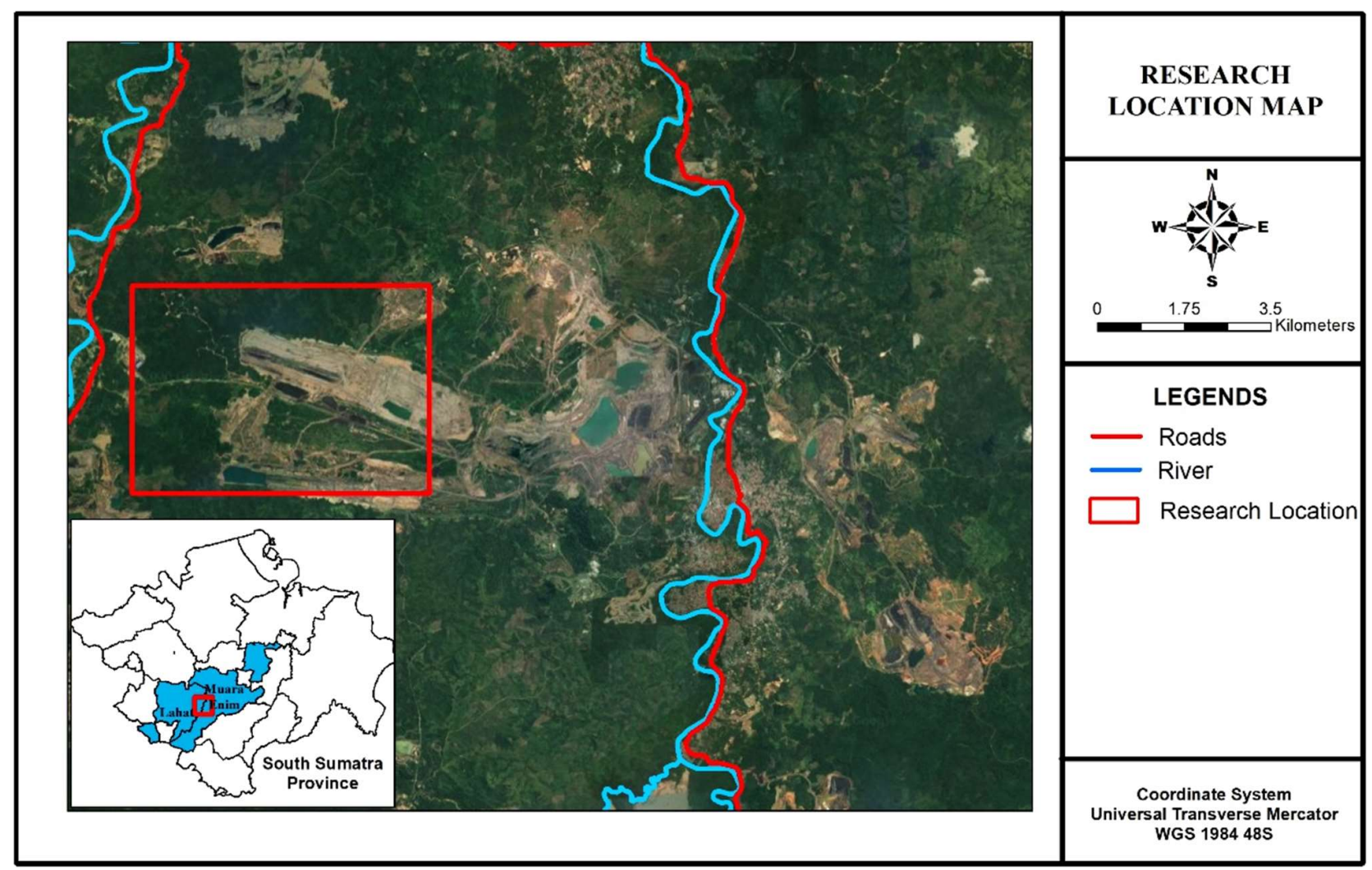

FIGURE 1. Research location in Muara Enim.

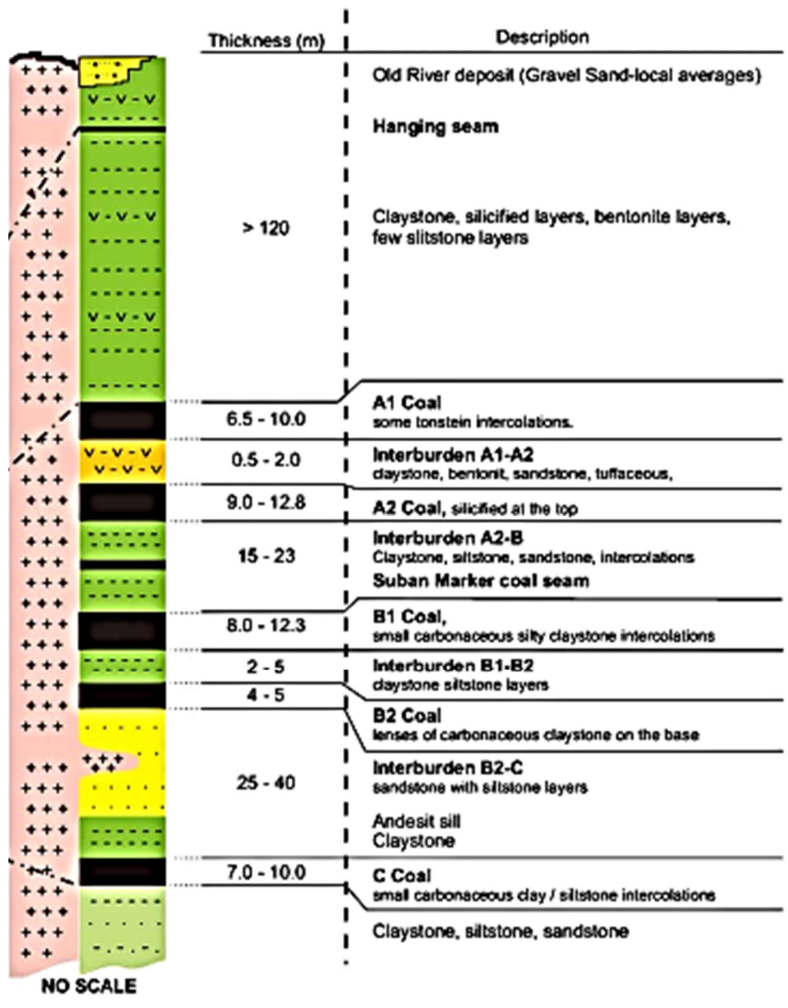

FIGURE 2. Stratigraphy of Muara Enim Formation (Susilawati and Ward, 2006).
NNP method, the grid block uses the closest borehole value for samples or composite data. This method does not have an average value from a different sample. Original variances of data are retained. There is no smoothing, and the value from one block to the next changes abruptly results in artificial discontinuity (Rossi and Deutsch, 2014). The method is suitable for the data to have evenly distributed but needs to be transformed into a Surfer format file. It is also useful to fills in the blank data where only a few data are missing and close to the grid (Yang et al., 2004).

\subsection{Inverse distance weighted (IDW)}

IDW method assumes that the degree of correlation and similarities between neighbors is proportional to the distance between them, which can be defined as a function of reversing each point's distance from a neighboring point (Setianto and Triandini, 2013). The main factor influencing the inverse distance interpolator's accuracy is the Power parameter $(P)$ (Burrough and McDonnell, 1998). Weighting is given to the data by a weighting power, which controls how the weighting factors decrease as the grid 


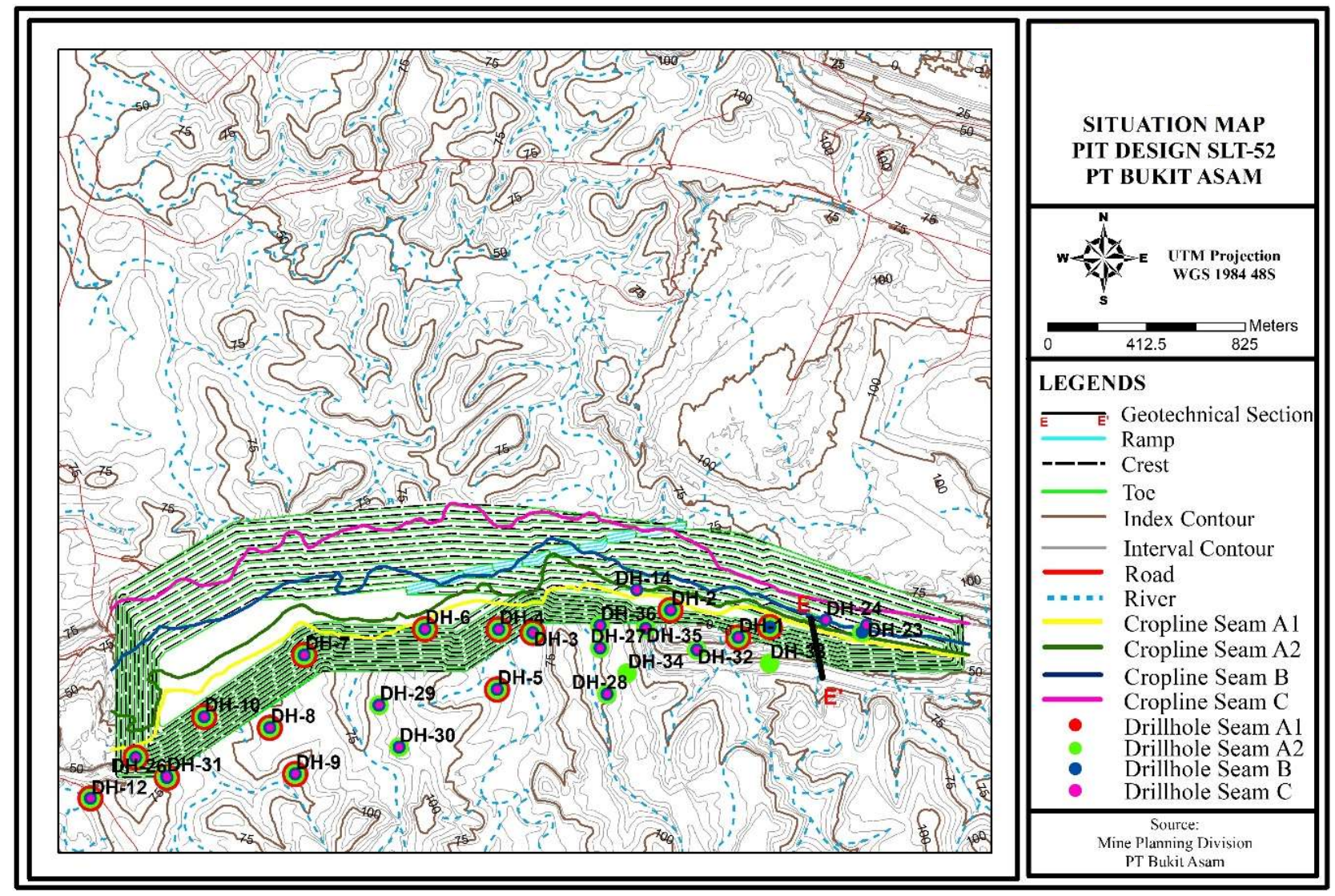

FIGURE 3. Pit design using the optimum slope in the research area (Wijayanto, 2020).

node's distance increases. Greater weighting power has less effect on the points and removed far data from the grid node through interpolation. The grid node value comes close to the nearest point value due to power increases. The weights are more evenly distributed among the neighboring data points when it has smaller power (Yang et al., 2004). The formula of the IDW method can be written as follows:

$$
\mathrm{Z}_{0}=\frac{\sum_{i=1}^{N} z_{i} \cdot d_{i}^{-n}}{\sum_{i=1}^{N} d_{i}^{-n}}
$$

where,

$Z_{0}=$ Estimated value of variable $Z$ in point $i$

$z_{i}=$ Sample value in point $i$

$d_{i}=$ Distance between the sample point and the estimated point

$N=$ Coefficient that determines the weight based on distance $n=$ Total number of predictions for each validation case

\subsection{Kriging}

Kriging is introduced as a geostatistical method used to estimate various regional variables, which usually results in small variance estimates (Journel, 1993). Ordinary kriging is the most basic of the Kriging methods. This method produces estimation at a location for which there is no data based on the weighting average of the adjacent observation locations (Setianto and Triandini, 2013). Estimation of weighted averages by ordinary kriging at locations where there are no samples $z\left(s_{0}\right)$ can be defined as follows:

$$
Z\left(s_{0}\right)=\sum_{i=1}^{n} \lambda_{i} z\left(s_{i}\right)
$$

Where $\lambda$ is the weight set in each sample that is being observed. This weight amounts to one so that the predicted value gives an unbiased estimate. 


$$
\sum_{i=1}^{n} \lambda_{i}=1
$$

The weight is calculated from the matrix formula:

$$
C=A^{-1} \times b
$$

where:

$A=\mathrm{A}$ semi-variance matrix between data points

$b=$ Semivariate prediction vector between the data points and the point where the $\mathrm{z}$ variable will be predicted.

$C=$ The resulting weights.

\subsection{Accuracy Test}

The accuracy of an interpolated model can be verified by cross-validation. This validation process uses the Root Mean Square Error (RMSE) method. The method is often used to calculate the number of error values (Bostan et al., 2012). The smaller the RMSE value, the better the accuracy of the calculation model (Aydin et al., 2018). The RMSE formula is as follows:

$$
\begin{gathered}
R M S E=\sqrt{\frac{1}{n} \sum_{i=1}^{n}\left(Z\left(s_{i}\right)-\hat{Z}\left(s_{i}\right)\right)^{2}} \\
R M S E=\sqrt{\sum_{i=1}^{n} \frac{(\text { Experimental }- \text { Model Predictions })^{2}}{N}}
\end{gathered}
$$

where,

$Z=$ Value of observation result

$\hat{Z}=$ Value of prediction result

$$
n=\text { Amount of data }
$$

\subsection{Volume calculation}

Golden Surfer 13 Software uses three-volume estimation methods: Trapezoidal Rule, Simpson's Rule, and Simpson's 3/8 Rule. The volume estimation in this research used the Trapezoidal Rule formula as the basis for its calculation (Golden Software, 2015), with the following formula:

$$
\begin{aligned}
A_{i}= & \frac{\Delta x}{2}\left(G_{i, 1}+2 G_{i, 2}+2 G_{i, 3}+\cdots\right. \\
& \left.+2 G_{i, n C o l-1}+G_{i, n C o l}\right)
\end{aligned}
$$

$$
\begin{aligned}
\text { Volume }= & \frac{\Delta y}{2}\left(A_{1}+2 A_{2}+2 A_{3}+\cdots\right. \\
& \left.+2 A_{n \mathrm{Col}-1}+A_{n \mathrm{Col}}\right)
\end{aligned}
$$

where,

$\Delta x=$ Grid column spacing

$\Delta y=$ Grid row spacing

$G_{i j}=$ Grid node value in i row and $\mathrm{j}$ column.

\section{REsults}

\subsection{Geological condition}

Coal deposits in the study area belong to the Muara Enim Formation that consists of seam $A 1$, seam $A 2$, seam $B$, and seam $C$ as shown in Figure 2 (Susilawati and Ward, 2006). Drilling data shows the stratigraphic layer above the A1 seam called overburden A1 is composed of claystone. Underneath it is a seam A1 with an average thickness of $6.67 \mathrm{~m}$, and below that, there is an inter burden layer A1-A2 composed of sandstones. Underneath it, there is an A2 seam that has an average thickness of $11.03 \mathrm{~m}$, and underneath the A2 seam, there is an A2-B inter burden layer composed of clay stones. Below that, there is seam $B$, which has an average thickness of $15.28 \mathrm{~m}$, then at the bottom of seam $\mathrm{B}$, there is a layer of inter burden $\mathrm{B}-\mathrm{C}$, which is composed of sandstones. Underneath it, there is a seam $C$, which has an average thickness of $7.23 \mathrm{~m}$, and the lowest layer is an under burden $\mathrm{C}$ layer composed of clay stones.

\subsection{Pit design}

Estimated coal reserves are based on existing pit designs. This study's pit design uses an arrangement with a $52^{\circ}$ single slope of the high wall and a $25^{\circ}$ in the low wall (Wijayanto, 2020). The parameter in designing pits considering the aspects of the slope geometry with a width of 10 meters and a height of 10 meters and the haul road's width is 30 meters based on calculating the total width of the haul road needed, namely HD-785. The pit design used the most optimal slope with the minimum safety factor 
value of 1.25 (Bowles, 1979). The pit design and slope stability analysis results in the most critical slope, as shown in Figure 3 and 4 (Wijayanto, 2020).

\subsection{Reserves estimation}

Reserves estimation needs to consider the minimum coal thickness for an estimated $>0.4$ meters for hard coal and $>1$ meter for brown coal (BSN, 1999). Coal thickness data is obtained from drilling data. The drilling is located near the high wall pit slope, as shown in Figure 3. Drilling thickness statistics in Table 1 show that the thickness of existing coal still meets these criteria. Coal in the study area has a strike value $\mathrm{N} 87^{\circ} \mathrm{E}$ and dip value $15-40^{\circ}$ to the south, as shown the Figure 3. Coal quality in Seam A1 coal rank is Sub-Bituminous C Coal, Seam A2 coal rank is Sub-Bituminous C Coal, Seam B coal rank is Sub-Bituminous C Coal, and Seam C coal rank is Sub-Bituminous B (Wijayanto, 2020). Therefore, the coal in this area is classified as sub-bituminous coal. It consists of coal seam B with a calorific value $<7000$ calories/gram (DAF) and coal seams A1, A2, C with calorific value $>7000$ calories $/$ gram $(\mathrm{DAF})$. The average specific gravity of coal is $1.3 \mathrm{gr} / \mathrm{cm}^{3}$. The results of the estimated reserves for each interpolation method are as follows:

\section{NNP}

In the NNP method, the interpolation is done by making the closest area of influence from the existing borehole. The area of influence was used to estimate a coal reserve. The results of the interpolation of coal thickness using the NNP method are shown in Figure 5. The estimated reserves using the NNP are shown in Table 2 .

\section{IDW}

Interpolation in the IDW method used the inverse of the distance of the borehole's influence at the point that it will be estimated. In this study, the value of power two is applied as a parameter for interpolation. The interpolation of coal thickness using the IDW method is shown in Figure 6 and the estimated reserves, as shown in Table 3.

\section{Kriging}

Kriging is one of the most accurate interpolation methods in its calculation with a relatively small error value (Rossi and Deutsch, 2014). The results of the interpolation of coal thickness using the Kriging method are shown in Figure 7 and the reserves estimation using the kriging method in Table 4.

\section{Discussion}

The selection of the best method for estimating coal reserves is based on the smallest RMSE value. This RMSE value is useful for determining the accuracy of the coal reserve estimation method. The difference between the value of the sample data taken and the prediction results' value is the error value of the assessment at the location (Purnomo, 2018). In the Golden Surfer 13 software, when interpolating the coal seam's thickness, it must do cross-validation to get the residual value, which is the difference between the model and actual values. RMSE calculations are carried out for each interpolation of coal thickness on Seam A1, Seam A2, Seam B, and Seam C using Equation 7. The results of RMSE calculations for each seam, as shown in Table 5. The analysis of the average RMSE values for all seams shows that kriging has the lowest value. The value of the average RMSE for the kriging method is 0.67 , where IDW and NNP methods have an average RMSE of more than 1. Therefore, in this case, it can be concluded that the Kriging method is the most accurate in estimating coal reserves in this study.

\section{CONCLUSION}

Estimation of coal reserves in the Muara Tiga Besar Mining Area, Muara Enim, PT. Bukit Asam, Indonesia, by using existing pit design with four-seam layers. The pit design has a single slope with a $52^{\circ}$ in the high wall and $25^{\circ}$ in the low wall. The result of coal reserve estimation using the NNP method is $28,006,812$ tons. In comparison, the IDW method's output is 27,994,169 tons, and the Kriging method $27,801,543$ tons. The lowest RMSE value is 0.67 by kriging methods. Therefore, the most suitable method for coal reserve estimation in this area is kriging. 


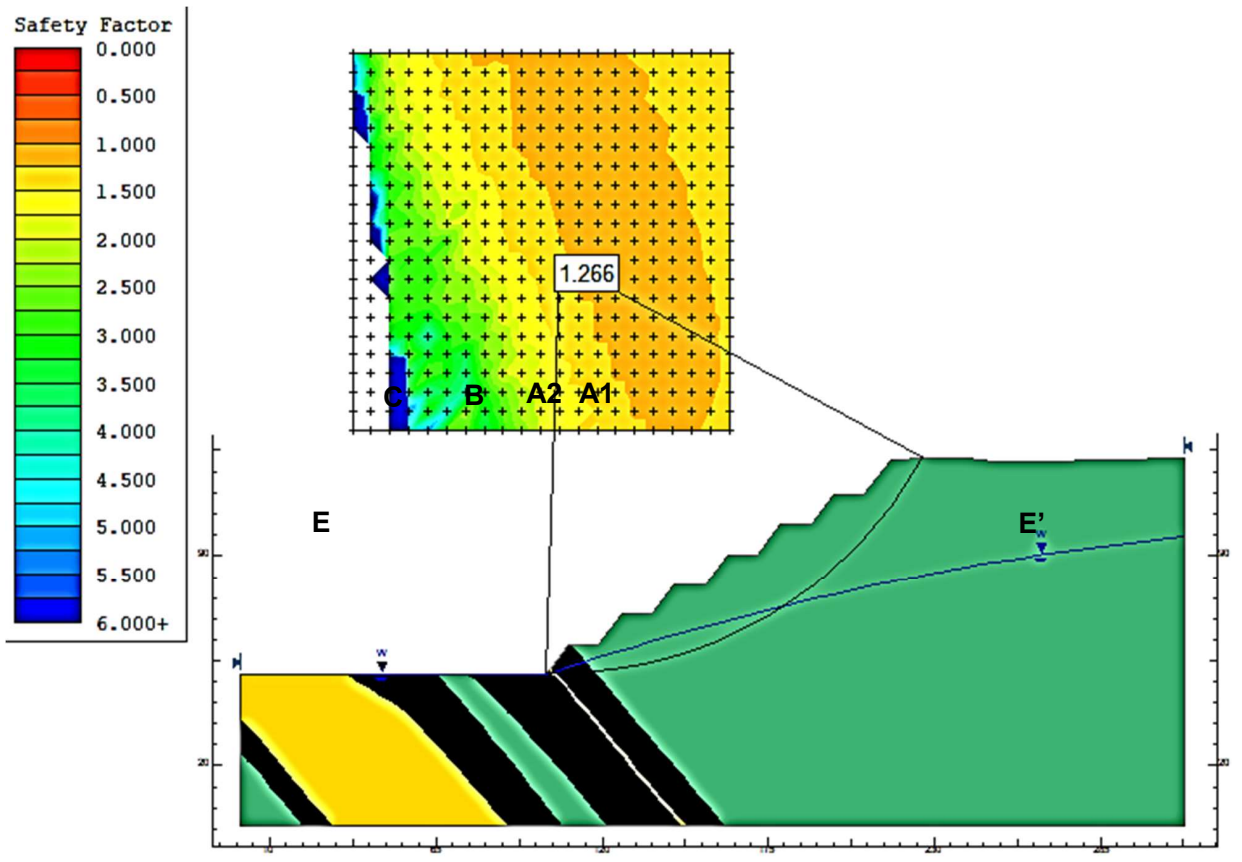

FIGURE 4 . Slope stability analysis in section C-C' with slope angle $52^{\circ}$ (Wijayanto, 2020).

TABLE 1. Recapitulation results of coal thickness statistical analysis from drilling data.

\begin{tabular}{lccccccc}
\hline Seam & \multicolumn{7}{c}{ Statistical analysis parameters } \\
\cline { 2 - 8 } & $\begin{array}{c}\text { Drilling } \\
\text { Data }\end{array}$ & $\begin{array}{c}\text { Maximum } \\
(\mathrm{m})\end{array}$ & $\begin{array}{c}\text { Minimum } \\
(\mathrm{m})\end{array}$ & Range $(\mathrm{m})$ & $\begin{array}{c}\text { Average } \\
(\mathrm{m})\end{array}$ & $\begin{array}{c}\text { Median } \\
(\mathrm{m})\end{array}$ & $\begin{array}{c}\text { Standard } \\
\text { Deviation }\end{array}$ \\
\hline A1 & 15 & 8.68 & 4.42 & 4.26 & 6.67 & 6.64 & 1.12 \\
$\mathrm{~A} 2$ & 26 & 29.24 & 9.26 & 19.99 & 11.03 & 10.16 & 3.82 \\
$\mathrm{~B}$ & 27 & 28.01 & 10.25 & 17.77 & 15.28 & 14.17 & 4.07 \\
$\mathrm{C}$ & 25 & 11.47 & 5.28 & 6.18 & 7.23 & 6.88 & 1.49 \\
\hline
\end{tabular}


NNP Seam A1

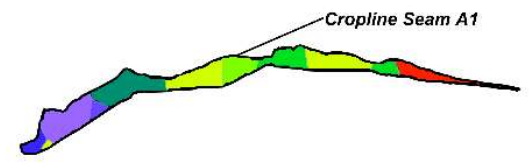

NNP Seam B

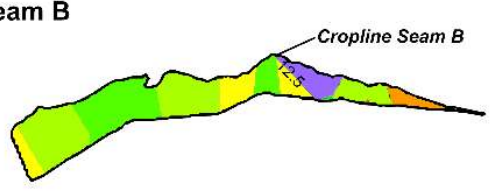

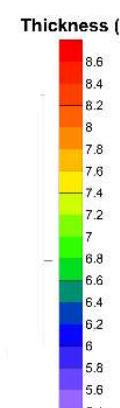

NNP Seam A2

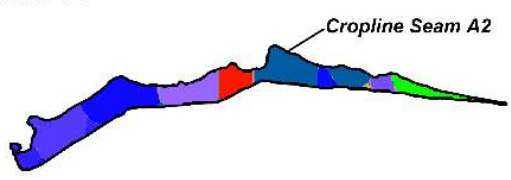

Thickness (m)

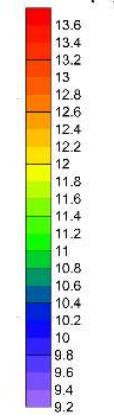

Thickness ( $m$ )
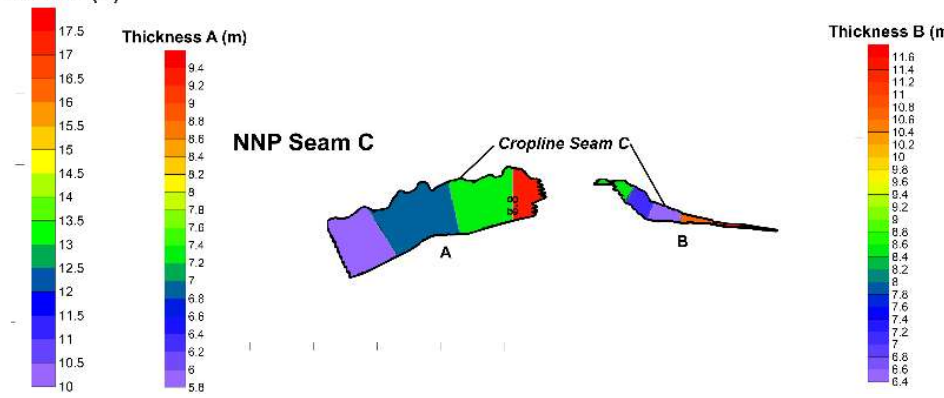

FIGURE 5. The result of NNP interpolation (black polygon is the coal seam area and color indicate the coal thickness).

IDW Seam A1

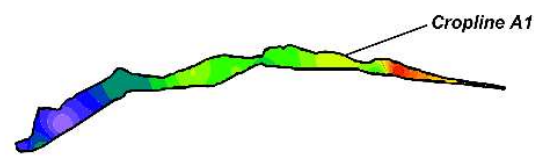

IDW Seam B

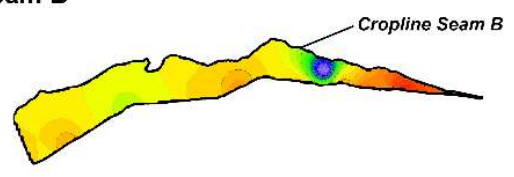

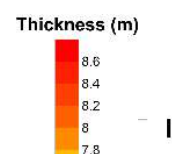

IDW Seam A2

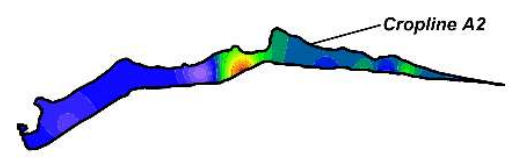

Thickness (m)

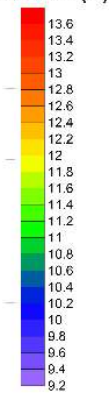

Thickness (m)

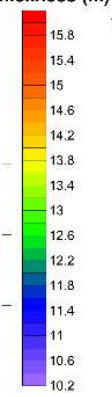

ickness A (m)
7.9
7.8
7.7
7.6
$7.5 \quad$ IDW
7.5

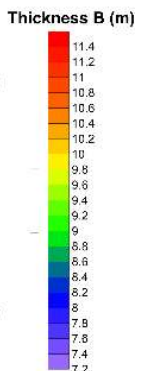

FIGURE 6. The result of IDW interpolation (black polygon is the coal seam area and color indicate the coal thickness). 
Kriging Seam A1

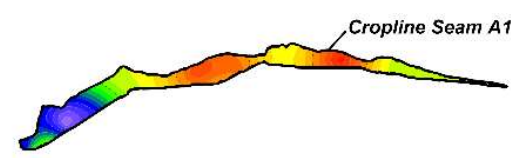

\section{Kriging Seam B}

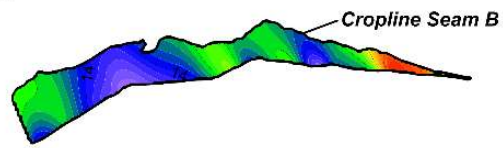

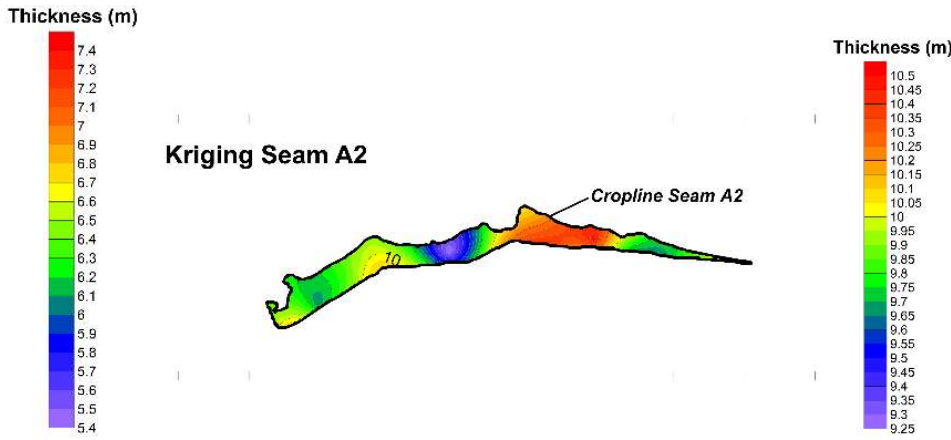

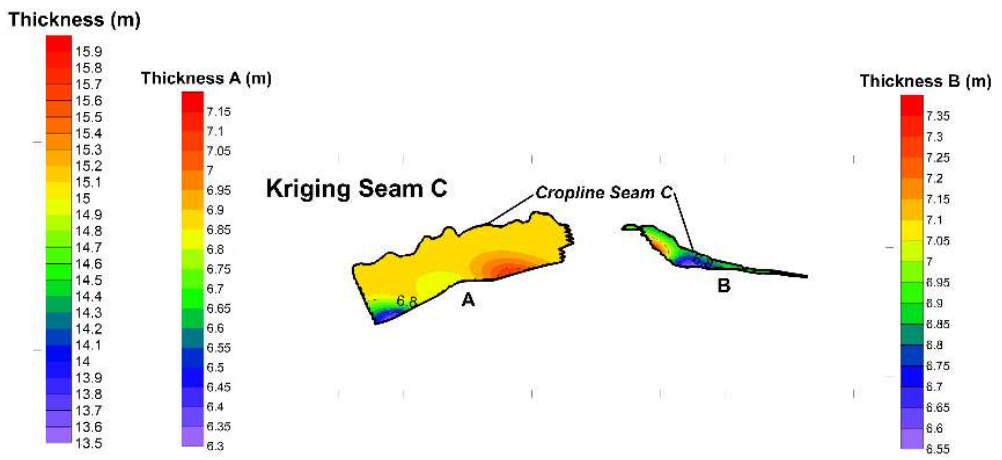

FIGURE 7. Kriging interpolation results (black polygon is the coal seam area and color indicate the coal thickness)).

TABLE 2. Reserve estimation results using the NNP method.

\begin{tabular}{lccc}
\hline Seam & $\begin{array}{c}\text { Thickness } \\
(\mathrm{m})\end{array}$ & $\begin{array}{c}\text { Estimated } \\
\text { Area }\left(\mathrm{m}^{2}\right)\end{array}$ & $\begin{array}{c}\text { Reserves } \\
(\text { Ton })\end{array}$ \\
\hline A1 & 6.72 & 328,117 & $3,065,984$ \\
A2 & 10.31 & 442,064 & $6,167,646$ \\
B & 13.92 & 673,965 & $12,284,200$ \\
C & 7.45 & 699,459 & $6,488,982$ \\
\hline & & Total & $28,006,812$ \\
\hline
\end{tabular}

TABLE 3. Reserve estimation results using the IDW method.

\begin{tabular}{lccc}
\hline Seam & $\begin{array}{c}\text { Thickness } \\
(\mathrm{m})\end{array}$ & $\begin{array}{c}\text { Estimated } \\
\text { Area }\left(\mathrm{m}^{2}\right)\end{array}$ & $\begin{array}{c}\text { Reserves } \\
(\text { Ton })\end{array}$ \\
\hline A1 & 6.72 & 328,117 & $3,067,436$ \\
A2 & 10.34 & 442,064 & $6,182,241$ \\
B & 14.08 & 673,965 & $12,248,691$ \\
C & 7.49 & 699,459 & $6,495,800$ \\
\hline & & Total & $27,994,169$ \\
\hline
\end{tabular}

TABLE 4. Reserve estimation results using the Kriging method.

\begin{tabular}{lccc}
\hline Seam & $\begin{array}{c}\text { Thickness } \\
(\mathrm{m})\end{array}$ & $\begin{array}{c}\text { Estimated } \\
\text { Area }\left(\mathrm{m}^{2}\right)\end{array}$ & $\begin{array}{c}\text { Reserves } \\
(\text { Ton })\end{array}$ \\
\hline A1 & 6.54 & 328,117 & $2,984,237$ \\
A2 & 9.92 & 442,064 & $5,931,440$ \\
B & 14.28 & 673,965 & $12,601,109$ \\
C & 6.88 & 699,459 & $6,284,757$ \\
\hline & & Total & $27,801,543$ \\
\hline
\end{tabular}

TABLE 5. RMSE value for each seam coal thickness interpolation.

\begin{tabular}{lccccc}
\hline \multirow{2}{*}{ Methods } & \multicolumn{4}{c}{ RMSE } & Average \\
\cline { 2 - 5 } & Seam & Seam & Seam & Seam & RMSE \\
& A1 & A2 & B & C & \\
\hline NNP & 1.66 & 1.62 & 1.41 & 1.39 & 1.52 \\
IDW & 1.4 & 1.01 & 1.33 & 1.04 & 1.19 \\
Kriging & 0.73 & 0.34 & 0.83 & 0.79 & 0.67 \\
\hline
\end{tabular}




\section{ACKNOWLEDGEMENTS}

We would like to thanks Mr. Eko Pujiantoro as the Long-Term Planning Manager of PT. Bukit Asam which permitted to conduct the research and publish the result. We also want to thank all staff at PT. Bukit Asam for support during the data collection. The financial support was provided by the Department of Geological Engineering, Gadjah Mada University.

\section{REFERENCES}

Aydin, E.S., Yucel, O., and Sadikoglu, H. (2018) Numerical Investigation of Fixed - Bed Downdraft Woody Biomass Gasification, in Dincer, I., Colpan, C.O., and Kizilkan, O. Exergetic, Energetic and Environmental Dimensions: Academic Press, p. $323-339$.

Badan Standarisasi Nasional (BSN) (1999) Pedoman Pelaporan, sumberdaya dan cadangan mineral. SNI 13-6011-1999: Standar Nasional Indonesia: p. 1 - 13. Bishop, M.G (2001) South Sumatra Basin Province, Indonesia: The Lahat/Talang Akar Cenozoic Total Petroleum System. U.S. Geological Survey Open-File Report: 22 p.

Bostan, P.A., Heuvelink, G.B.M., and Akyurek, S.Z. (2012) Comparison of regression and kriging techniques for mapping the average annual precipitation of Turkey: International Journal of Applied Earth Observation and Geoinformation vol. 19, p. $115-126$.

Bowles, J. E. (1979) Physical and Geotechnical Properties of Soils, McGraw-Hill Book Compan. New York, $478 \mathrm{pp}$.

Burrough, P.A., and McDonnell, R.A. (1998) Principles of Geographical Information Systems. Oxford University Press, Oxford. 332p.

Dag, A. and Ozdemir, A.C. (2013) A Comparative Study for 3D Surface Modeling of Coal Deposit by Spatial Interpolation Approaches. Resource Geology, Vol. 63, No 4: p. 394-403.

De Coster, D.L. (1974) The Geology of The Central and South Sumatra Basins, Proceedings Indonesia Petroleum Association 3rd Annual Convention p.77-110.

Golden Software (2015) Surfer 13 Full User's Guide. Golden Software, $168 \mathrm{p}$.

Hartman, H.L. (1992) SME Mining Engineering Handbook. Society for Mining, Metallurgy, and Exploration Inc.,

Journel, A.G. (1993) Geostatistics: Roadblocks and Challenges, In Soares A, 1992, Geostatistics Tróia '92: Quantitative Geology and Geostatistics, vol 5, p. $213-224$.
Laksono, A.D., Muchsin, A.M., dan Guntoro, D. (2018) Permodelan dan Estimasi Sumberdaya Batubara (Studi kasus wilayah IUP CV. Atap Tri Utama Kecamatan Muarajawa, Kabupaten Kutai Kartanegara, Provinsi Kalimantan Timur). Prosiding Teknik Pertambangan: p. 49-56.

Oktaviani, K. (2018) Rekonsiliasi Data, Sumber Daya Batubara Indonesia Kini 166 Miliar Ton, Cadangan 37 Miliar Ton (Accessed June 2019).

Pujobroto, A. (1997) Organic petrology and geochemistry of Bukit Asam coal, South Sumatra, Indonesia, Doctor of Philosophy thesis, School of Geosciences, University of Wollongong. 612p.

Purnomo, H. (2018) Aplikasi Metode Interpolasi Inverse Distance Weighting dalam Penaksiran Sumberdaya Laterit Nikel, Angkasa: Jurnal Ilmiah Bidang Teknologi, 10(1), p. 49-60.

Rossi, M.E., and Deutsch, C.V. (2014) Mineral Resource Estimation, Springer, $337 \mathrm{p}$.

Setianto, A., and Triandini, T. (2013) Comparison of Kriging and Inverse Distance Weighted (IDW) Interpolation Methods in Lineament Extraction And Analysis. J. SE Asian Appl. Geol, Vol. 5(1), p 21-29.

Stalder, P. (1976) A review of the south sumatra coal basin. Shell Minjbouw N.V., Jakarta. 17p.

Subastedjo (1983) Penyelidikan Geologi Untuk Perencanaan Tambang Batubara: Conto Kasus Perencanaan Tambang Batubara Muara Tiga, Bukit Asam, Sumatra Selatan. PIT XII Ikatan Ahli Geologi Indonesia, 13: p. $209-213$.

Susilawati, R. and Ward, C.R. (2006) Metamorphism of mineral matter in coal from the Bukit Asam deposit, South Sumatra, Indonesia. International Journal of Coal Geology 68: p. 171 - 195.

Widodo, S., Anshariah, dan Masulili, F.A. (2015) Studi Perbandingan Antara Metode Poligon Dan Inverse Distance Pada Perhitungan Cadangan Ni PT. Cipta Mandiri Putra Perkasa Kabupaten Morowali, Jurnal Geomine, Vol 03, 148 - 154.

Wijayanto, T.M. (2020) Desain Pit Tambang dan Perencanaan Operasional Produksi Tambang Batubara Unit Pertambangan Tanjung Enim PT. Bukit Asam Tbk (Unpublished Thesis): Universitas Gadjah Mada, 272 p.

Wood Jr, G.H., Kehn, T.M., Carter, M.D., and Culbertson, W.C. (1983) Coal Resource Classification System of the U.S. Geological Survey. The United States of America, United States Geological Survey: $65 \mathrm{p}$.

Yang, C.S., Kao, Szu-Pyng, Lee, F.B., Hung, P.-S. (2004). Twelve different interpolation methods: A case study of Surfer 8.0. Proceedings of the XXth ISPRS Congress: p. 778-785. 